KAIROS ELT JOURNAL, Vol. 1, No. 3, December 2017

Copyright@2017, ISSN: 2580-4278

\title{
THE ABILITY OF THE SECOND YEAR STUDENTS OF SMP KATOLIK TRISAKTI 1 MEDAN IN USING VERB BE
}

\author{
Berkat Aman Zebua, Viator Lumban Raja, Fiber Yun A Ginting \\ Catholic University of Saint Thomas
}

\begin{abstract}
Grammar is a description of certain organizing aspects of a written particular language. One of the grammar topic is verb BE. Verb BE is important in English Grammar, BE is the one of the elementary and earlier phases of subject verb agreement. The purpose of this research was to describe the ability of the second year students in using verb BE. This research was descriptive research. The population of this research was the second year students were take as a sample, and totals 40 students. The instrument of collecting data was a test concerning verb BE. The try out test was done in order to know the validity, reliability, item difficulty and power discrimination of test items. The result showed that 9 students $(22.50 \%)$ belong to high category, 28 students (70\%) to moderate category, and 3 students $(7.50 \%)$ to low category. The mean score was 65.10 it was only $30 \%$ of the total students who can do the test well with 12 students who get score above 70. It means that the second year students at SMP Katolik Trisakti 1 Medan are not yet able to use the verb BE. Some students do not understand the rule of verb $\mathrm{BE}$, how to apply it in sentences because there were a lot of rules and exception in verb BE. The students also had some difficulties in using verb BE. The students did not know the form of some tenses such as simple present tense, simple past tense etc. Based on the total incorrect answers made by the students in each tense was 349 . The percentage students mistakes made using verb Be in Present Tense was $28.57 \%$, and the percentage students mistakes made using verb Be in Past Tense was $11.46 \%$, So the most mistakes made by the second year students in using verb Be was in present tense, the percentage was $28.57 \%$. Thus, the students are suggested to study more the lesson of verb $\mathrm{BE}$ and to do the assignments well. The teacher also expected to give explanation of the materials of verb BE crearly.
\end{abstract}

Keyword: grammar, verb be

\section{INTRODUCTION}

Language is a system of human communication to express their culture and needs. With language human beings can communicate with each others and make sense of complex and abstract thought. Besides, human beings can fullfill their daily needs as well as to estabilish rules and maintain their culture through language. For that reason, language is a perfect instrument for human communication (Limbong, 2020).

Language has an important role in human life because without language there is no life. Language is an instrument to share information, discuss something people need, exchange knowledge, belief, opinions, etc. People also express their culture through language, that is why language and culture are closely related, one cannot exist without the other, they complete each other.

There are many languages in this world that can be used to communicate such as English, Mandarin, Japenase, Indonesian etc. Every country has more than one language that the people usually use to communicate with others in their daily activities. People must master a language to communicate so that they can share and give the information to one another. 
Nowadays, English is the most commonly used by most countries. It is not only used to apply for a job but also to communicate with other people from different nations. The development of science and techonology is mostly written in English and people must understand English in order to read it. English has been the most important language as an international communication because almost all people all over the world speak in English.

English has four important components that should be mastered by the students, namely listening, speaking, reading and writing. To master all of them, of course a part of grammar plays an important role. Without grammar, students cannot understand the language well. Therefore, in studying English grammar especially the verb $B E$ is absolutely needed. Students who have poor grammar and lack of structure skill will never speak well. On the other hand, with the rich grammar, the students can comperehend and speak a great deal of English. Grammar is the rule of how words are put together and how it works.

According to Francis, (1954:109) grammar is the set of formal patterns in which the words of a language are arranged in order to convey large meanings. Grammar determines how words are arranged to form meaningful units. It is clear that grammar is intended to make English good and well for the students or learners to be able to communicate in English to express their ideas in oral and written form.

There are many functions of grammar including structure of words, phrases, clauses, and sentences, right up to the structure of whole text. One of the small grammar is verb. Hall (1993:33) states there is one class of verbs in English that uses different sentence patterns, these verbs are called linking verb, the most common of them is $B E$. The verb $B E$ has a lot of meanings, and at least two functions.

1. He is a teacher. (indicating a profession)

2. He was sick. (experience)

3. He was in Bali. (indicating location)

Based on the sentence function, a teacher and sick are called subject attribute, whereas in Bali is adverbial. The verb $B E$ can function as auxiliary in progressive tense and passive voice.

1. I am baking chocolate-broccoli muffins today. (Present Progressive)

2. Naomi was hoping for an A in her organic chemistry class. (Past Progressive)

3. I will be growing broccoli in the backyard this spring. (Future Progressive)

4. Our lips were licked by us. (Passive Voice)

Based on the sentence function, Am, was, will be are auxiliary verb. Baking, hoping, growing are present participle completing the verb phrase, whereas our lips is as subject, were is form of $B E$, licked + by is past participle and us is an agent. For more details of verb $B E$ it will be discussed in the next chapter.

The verb $B E$ is the one of the elementary and earlier phases of subject-verb agreement. (Azar \& Hagen, 2006) It is also one of the most challenging structures in the English language to acquire. (Arshad and Hawanum, 2010) states that Malaysian students have difficulty in mastering the verb $B E$. They encompass various functions which include copula $B E$, progressive auxiliary and passive forms. (Saadiyah and Subramaniam, 2009) argue that the interference from the learners' first language in which the auxiliary $B E$ is absent hinders students from fully learning it. (Surina and Kamaruzaman, 2009) cite confusion based on varied uses of the verb $B E$ as the cause of their inability to use the form accurately.

Saadiyah and Subramanian (2009) examined errors in 72 essays written by 72 students, their findings indicated that students were likely to commit errors using the auxiliary $B E$ in their writing. (Farhanaz, 2007) studied written essays and syntax tasks completed by 160 students from a higher learning institution in Malaysia. He found out that the level of proficiency affects students' acquisition of the verb $B E$ in which students of better proficiency produce more correct form of the verb $B E$ in comparison with those whose proficiency is lower. The study also revealed that errors in using verb $B E$ committed by ESL learners, usually include 
addition, inflection, marker, omission, prurality/singularity, repetition, substitution, tense, and word order.

Based on the writer's observation, there are many students of SMP Katolik Trisakti 1 Medan who have many difficulties in using verb $B E$, because each student has different background knowledge. For example, they do not pay attention when they answer the question about verb $B E$. It is proved that when the writer took his internship program at SMP Katolik Trisakti 1 Medan, the writer taught in a classroom and carried out the dialogue with some students in English. Many students still cannot use good grammar especially in using verb $B E$ even though the writer speaks slowly in English. In other words, students were not able to express their ideas in English because when they speak and write, the students must think about grammar first. For that reason, the writer intends to conduct a research about the students' ability in using verb $B E$. The students will be given a test concerning the use of verb $B E$ in order to know their ability about it.

\section{REVIEW OF LITERATURE \\ Grammar}

In English, students should know the grammar. Grammar is one of the components in language learning that has been taught how to use words in English. There four important aspects that should be mastered, namely listening, speaking, reading and writing. To master all of them, of course, grammar plays an important role. Grammar is part of English study which concerns with the rules of sentence contruction. Without grammar, students cannot speak and write well in English. Grammar refers to the language resources used to organize words into structural patterns that make the meanings of sentences. Baker (1992 : 33) states grammar is the set of rules which determine the way in which units such as words and phrases can be combined in a language and the kind of information which has to be made regularly explicit in utterance. Thus, grammar is very important in any language. There is no language which has not its specific grammar and not person can learn a language without learning its grammar.

According to Francis, (1954: 109) grammar is the system of patterns and structures, a set of resources used to organise words into sentences that make the meanings in a text. Grammar refers to the language resources used to organise words into structural patterns that make the meanings in sentence. Grammar is very important in English communication to make the pattern of sentence correct. Thus, English without grammar cannot make a correct pattern and sometimes people will be confused what to know a sentence means.

Grammar is very important in English and it can help one to learn about a language. By studying grammar seriously, the learner is able to make the words into sentences, from the word that does not have meaning into sentences that has meaning. In other words, grammar has many parts in English and one of them is verb. Verb is an important aspect in English to make grammar understood.

\section{The Verb}

According Wren \& Martin (1986:84) verb is a word that tells or asserts something about a person or thing. According Dykes (2007:41) A verb comes from Latin verbum, a word. Verb are a necessary component of all sentences. Some verbs put stalled subject into motion while other verb helps to clarify the subjects in meaningful ways. Peters (2004:57) states that there are three types of verb: Action verb, Helping verb, Linking verb.

Action verbs are words that express action (give, eat, walk, etc.).A linking verb connects the subject of a sentence to a noun or adjective that renames or describes the subject. The most common linking verb is the verb $B E$ in all of its forms (am, are, is, was, were, etc.). This verb may also be used as a helping verb. Helping verbs are used before action or linking 
KAIROS ELT JOURNAL, Vol. 1, No. 3, December 2017

Copyright@ 02017 , ISSN: 2580-4278

verbs to convey additional information regarding aspects of possibility. A verb is a word that tells or asserts something about a person or thing.

1. John is a student.

2. The man took to the hospital.

In (1) the verb is tells somethings about the subject, John that he is a student. In (2) the verb took tell something about the subject, the man, that took him to the hospital.

\section{The Concept of Ability}

The students of junior high school are individuals who are growing up and evolve in order to achieve a mature personality. The individuals grow with their physical aspects and attitude. In education and learning activities both physical aspects and attitude should serve them with a balancing way to make them have great personality and good character. They are expected to produce range of capabilities that they will use later in the future. Carrol (1993:4) states ability is actual power to perform an act, physical or mental, whether or not attained by training and education. Bhatia (2009:1) states that ability is a capacity or skill or is competence to perform anact without previous training. The term covers intelligence and specific aptitudes. The ability is the state of being able to do something or level of skill at doing something.

From the statement above it can be concluded that ability is someone's capability in doing something well by using knowledge and skill or something that people do very well because they have learned and praticed. The quality of being able to do something or act physically and mentally to accomplish someting. The level of ability is a measure of the success of learners to remember (recall) what they have get.

\section{The Description $B E$}

$B E$ can have many different forms depending on its subject and on its tense: present tense, past tense, present participle and the infinitive form. $B E$ can as a linking verb etc. Palmer $(1965: 15)$ states the verb $B E$ in relation to agreement has four forms.

\section{The infinitive form}

The structure $\boldsymbol{B} \boldsymbol{E}+$ infinitive is used to talk about official plans and arrangements in a formal style. For example :

1. The prime Minister is to visit Africa next month.

2. We are to get a wage rise in May.

$\boldsymbol{B} \boldsymbol{E}$ can be followed by a perfect infinitive (to have + past participle) to show that a planned event did not happen.

I was to have returned last month, but I changed my mind

\section{Orders}

$B E+$ infinitiveis common in orders. Parents and teachers often use this structure when speaking to their children and students.

1. You are to learn this poem by heart.

2. You are to do your homework before you can go out.

$\mathrm{BE}+$ passive infinitive

The structure $\boldsymbol{B} \boldsymbol{E}+$ passive infinitive (to be + past participle) is common in notice and instructions

1. The label is not to be removed.

2. The missing boy was no where to be found.

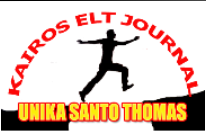


KAIROS ELT JOURNAL, Vol. 1, No. 3, December 2017

Copyright $\bigcirc 2017$, ISSN: 2580-4278

2. The present form

1. Simple Present Tense

a) Simple Present Tense with $B E$

If the subject is $I$, use $\boldsymbol{a m}$.

Examples:

1. I am a teacher.

2. I am often absent-minded.

3. I am in class every Wednesday at 10:00.

If the subject is you, we, or they, use are

Examples:

1. You are my sunshine.

2. We are so happy.

If the subject is a he, she, or it, use is.

Examples:

1. Berkat is the governor of Gunung Sitoli.

2. She is an English teacher.

b) Simple Present Negative with BE

Add $n o t$ after $\boldsymbol{B E}$.

Examples:

1. I am not a millionaire

2. They are not a students

3. George W. Bush is not my uncle.

\section{The Past Form}

\section{Simple Past Tense}

a). Simple Past Tense with $B E$

If the subject is $I$, he, she, or it, use was.

Examples:

1. I was a high school teacher before I started teaching college.

2. Tina was a student 5 years ago.

3. The weather was warm yesterday, but it's cold and windy today.

If the subject is you, we, or they, use were.

Examples:

1. You were always a stubborn child

2. Fred and Ethyl were upset when Lucy and Ricky wanted to break their lease.

3. We were in the third row.

b). Simple Past Tense negative with $B E$

Examples:

1. Norton was not a football player when he was in high school.

2. I was a not a student.

3. President and Mrs. Bush were not at my house last night, either.

c). Simple Past Tense Questions with $B E$

Examples:

1. Was I noisy when I was a baby?

2. Were you in class last Tuesday?

\subsection{Function of $B E$}

There two function of BE, they are:

1. Auxiliary Verb

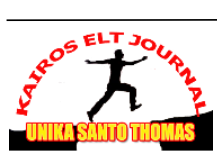


KAIROS ELT JOURNAL, Vol. 1, No. 3, December 2017

Copyright@2017, ISSN: 2580-4278

According to Fernald (1975: 81) Auxiliary verb are verbs of incomplete predication that is used with a principal verb to form phrase indicating tense, mood, or voice. Sometimes, they also called "helping verb". A helping verb helps the main verb to express action or make a statement. English has two types of auxiliary verbs finite forms and non-finite forms. They can be seen in the following table:

\section{Table 2.1 Non-Finite Forms and Finite Forms}

\begin{tabular}{|c|c|c|c|c|}
\hline \multicolumn{3}{|c|}{ Non- Finite forms } & \multicolumn{2}{|l|}{ Finite Forms } \\
\hline Infinitive & $\begin{array}{l}\text { Present } \\
\text { participle }\end{array}$ & $\begin{array}{l}\text { Past } \\
\text { participle }\end{array}$ & Present Tense & Past Tense \\
\hline $\begin{array}{l}B E \\
\text { HAVE } \\
\text { DO }\end{array}$ & $\begin{array}{l}\text { Being } \\
\text { Having } \\
\text { Doing }\end{array}$ & $\begin{array}{l}\text { Been } \\
\text { Had } \\
\text { Done }\end{array}$ & $\begin{array}{l}\text { Am, Is, Are } \\
\text { Have, Has } \\
\text { Do, Does } \\
\text { Shall } \\
\text { Will } \\
\text { Can } \\
\text { May } \\
\text { Must } \\
\text { Ought } \\
\text { Need } \\
\text { Dare }\end{array}$ & $\begin{array}{l}\text { Was, Were } \\
\text { Had } \\
\text { Did } \\
\text { Should } \\
\text { Would } \\
\text { Could might } \\
\text { used }\end{array}$ \\
\hline
\end{tabular}

Auxiliary verb serve grammatical functions, for this reason they are said to belong to the functional category of words. The main auxiliary verbs in English are DO, $B E$, and HAVE. Others, which serve to mark ASPECT, MOOD, and VOICE include, amongst others CAN, MAY, MIGHT, MUST, OUGHT TO, SHOULD, WILL and WOULD.

According to Peters (2004 : 57) the primary auxiliaries are HAVE, $B E$ and DO. HAVE and $B E$ have the special characteristic of combining with participles, present and past, in order to express aspect, and the passive voice. $H A V E$ and $B E$ never combine with the "bare"infinitive, as do the modal auxiliaries and the verb do itself. In the continuous flow of discourse, the auxiliaries $H A V E$ and $B E$ sometimes appear unaccompanied by participles, but this is when the relevant participle can be inferred from a previous sentence. Thus for example it is natural enough to say (or write):

1. I haven't met the new assistant yet. Have you?

The main verb participle met (and its object) are understood through the use of have in the question.

Primary auxiliaries can also stand alone as main/full/lexical verbs, as in:

1. He has a large office.

2. They are in the bottom drawer.

3. I do my homework.

In those cases, each verb carries its own lexical meaning: have a possessive meaning, $\boldsymbol{B E}$ an existential meaning, and $\boldsymbol{d o}$ is carry out.

\section{As Main Verb}

$\mathrm{BE}$ is function as main verb or full verb (commonly called verb) when there is no main verb (verb) after to be in a sentence. In this case to be is directly followed by adjective, adverb or noun.

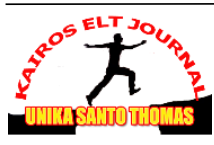


KAIROS ELT JOURNAL, Vol. 1, No. 3, December 2017

Copyright@2017, ISSN: 2580-4278

Example :

1. We are at home. (at home $=$ adverb of place)

2. She was sad.(sad=adjective)

3. This is my suitcase (my suitcase)

\section{Auxiliary $B E$}

In this role as an auxiliary verb, $B E$ can accour in either the present tense, past tense or past participle form.

$\begin{array}{lll}\text { Present } & \text { Past } & \text { Past Participle } \\ \text { Am } & \text { Was } & \text { Been } \\ \text { Are } & \text { Were } & \end{array}$

Is

The verb form following auxiliary $B E$ is usually a present participle form:

1. Frank was acting sick.

2. We were giving our donation to the charity.

3. They have been waiting for the guests all day.

Like have, $B E$ can function as either an auxiliary verb or main verb. If it is the right most verb in the verb phrase, otherwise, it is an auxiliary verb. There are five principle parts of $B E$ which can be displayed by other main verbs:

Infinitive

\section{$B E$}

Present

Am, Is, Are

Past

Was, Were

Present Participle

Being

Past Participle

Been

Auxiliary $B E$ has no intrinsic meaning, but serves the important function of marking tense and agreement features when there is no lexical verb present i.e. when the predicate is an adjective or a prepositional phrase, e.g.:

1. He is tall (adjectival predicate).

2. They were in the garden (preposition predicate).

In this sentences, the auxiliary serves to mark tense and it agrees with the subject with respect to number (singular or prular) and person $\left(1^{\text {st }}, 2^{\text {nd }}, 3^{\text {rd }}\right)$. Auxiliary $B E$ has far more forms than any of the other auxiliary verbs :

Table 2.2 The Form of $B E$ for the Present Tense

\begin{tabular}{|l|l|l|}
\hline \multirow{4}{*}{ Singular } & Person & Present Tense \\
\cline { 2 - 3 } & $1^{\text {st }}$ & I am happy \\
\cline { 2 - 3 } & $2^{\text {nd }}$ & You are happy \\
\cline { 2 - 3 } & $3^{\text {rd }}$ & He/she/it is happy \\
\hline Prular & $1^{\text {st }}, 2^{\text {nd }}, 3^{\text {rd }}$ & We/you/they are happy \\
\hline
\end{tabular}

In this case of the past tense, was is the form for $1^{\text {st }}$ and $3^{\text {rd }}$ person singular subjects and were is used for $2^{\text {nd }}$ person singular and all plural subjects :

Table 2.3 The Form of Auxiliary $B E$ for the Past Tense

\begin{tabular}{|l|l|l|}
\hline & Person & Past Tense \\
\hline Singular & $1^{\text {st } \& 3^{\text {rd }}}$ & I/he/she/it was happy \\
\hline
\end{tabular}


KAIROS ELT JOURNAL, Vol. 1, No. 3, December 2017

Copyright $\odot 2017$, ISSN: 2580-4278

\begin{tabular}{|l|l|l|}
\hline Plural & $2^{\text {nd }}$ & You were happy \\
\hline & $1^{\text {st }}, 2^{\text {nd }}, 3^{\text {rd }}$ & We/you/they were happy \\
\hline
\end{tabular}

\section{The meaning of $B E$} meaning :

The verb $B E$ can indicate several meanings. Swan (2005:81) states $B E$ has the following

1. Indicating existance

1. Air is Everywhere.

2. Is There another life?

3. Piramida is the old building.

2. Indicating Time

1. The exhibition is start 13.00 P.M.

2. They are to go to the zoo next week.

3 . What were you doing at 8 o'clock?

3. Indicating Cost

1. These books are $\$ 3$ each.

2. My computer is $\$ 520$.

3. These xxx cinema tickets were IDR 35,000.00.

4. Indicating manner/attitude

1. She is a kind person.

2. All my lecturer are very kind person.

3. He was a lazy person in the compony.

5. Indicating Place

1. Where is the police station?.

2. They were in the town hall last night.

3. They are working in the Pentagon office.

6. Indicating Profession

1. He is a policeman.

2. Bill gates is a rich man in the world.

3. Mitha was a student three years ago.

7. Indicating Size

1. Is there M size in your store?

2. What size are your shoes?

3. They were found the right size.

8. Indicating existence

1. There is a bag on the table.

2. She was wounded in the accident.

3. The food was already on the table.

9. Indicating Happening/occurence

1. The meeting is now.

2. She was never to see her brother again.

3. When they are go to the the place they will never back.

10. Become

1. They are to be married next month

2. She is to be a lawyer next year.

3. She was a nurse last year.

\section{RESEARCH METHOD}

This research uses descriptive research, by using number, beginning from collecting the data, interpretation toward the data, and the result was presented by describing and analizing

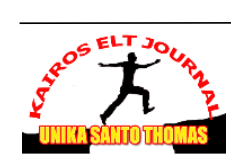


the data. Jonhson \& Christensen (2008:33) states quantitative research is research that relies primary on the collection of quantitative data. In quantitative descriptive research, they also state the aims is to describe the data and the characterstic about phenomeno under study but does not provide the reason for the situation. In this case, the writer investigates about students' ability in using verb $B E$ in present tense and past tense.

This research will be conducted at SMP Katolik Trisakti 1 Medan. It is located on Jl. H.M Joni No.52 A, Ps. Merah, Kecamatan Medan Area, Medan. There are four classes of second year students of SMP Katolik Trisakti 1 Medan. The writer chose this location beacuse there has never been other researchers who conducted the study with the same variable as the writer conducts. This study conducted in $7^{\text {th }}$ September 2017 and $14^{\text {th }}$ September 2017. Arikunto (2006:173) defines that population is all of the subjects who are connected to the research. Knight (2010:2) explained that population is the large group to which the result of the research can be generalized.

The population of this research is the second year students of SMP Katolik Trisakti 1 Medan. There are 4 classes in the second year students at school.

\section{Table 3.1 Population of the Research}

\begin{tabular}{|l|l|}
\hline The Second Years Students of SMP Katolik Trisakti 1 Medan \\
\hline Classes & Amount of Students \\
\hline 8A & 36 \\
\hline 8B & 36 \\
\hline 8C & 36 \\
\hline 8D & 36 \\
\hline Total & 144 \\
\hline
\end{tabular}

Jonhson \& Christense (2008:223) define that sample is set of element taken from a large population. The writer takes sample from $8 \mathrm{~A}, 8 \mathrm{~B}, 8 \mathrm{C}$, and $8 \mathrm{D}$ which consist of 10 students in each class. Therefore, there are 36 students as the sample. To decide the 10 students from each class the writer takes even and odd number by following student list of attendant in each class. The writer used test in collecting the data. Test first, the writer give a try out test to the students of 8 (A,B,C,D)-class which has 40 students every class and 10 students as sample each class. This try out test intended to know: the level of difficulty, the power discrimination of the test, the validity and realibility, the difficulties items, and the time needed.

This instrument used to collect the data is a test which concerns with the verb $B E$ in present tense and past tense. The test will be administered to the students, and they will work on it. The test consists of 15 items in multiple choice form, and 10 items in essay form. The score for each item is 4 , for correct answer. Then the score for one incorrect was 0 (zero). This test will last one hour. The students are instructed to choose and complete sentences in the right form.

In analyzing the data, the researcher analyzes the data of the ability of the second year students of SMP Katolik Trisakti 1 Medan in using verb BE. To analyze the data, the researcher followed the procedures that was suggested by Arikunto (2012:299) as follows;

- Calculating all of the students' score

- Calculating mean and standard deviation as follows:

$$
M=\frac{\sum f x}{N}
$$

Where: $\mathrm{M}=$ Mean

$\sum \mathrm{x}=$ Total score of the students

$\mathrm{N}=$ Number of the sample

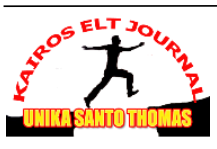


$S D=\sqrt{\frac{\sum f x^{2}}{N}-\left[\frac{\sum f x^{2}}{N}\right] 2}$

- Classifying the students' ability based on their group:

High ability $=>M+S D$

Moderate ability $\quad=$ Between $(\mathrm{M}-1 \mathrm{SD})$ and $(\mathrm{M}+1 \mathrm{SD})$

Low ability $=<M-S D$

- Calculating the percentage of students who get high, moderate, and low ability: $P \frac{R}{T} x 100 \%$

Where: $\mathrm{P}=$ Percentage of the students' ability

$\mathrm{R}=$ The sum of the students who get high, moderate, and low ability

$\mathrm{T}=$ The sum of the students

\section{DATA ANALYSIS}

\section{Try Out Test}

This is not the real subject of the research, but they are intended to do the try out test to decide the realibility of the test and the level of difficulty and item discrimination power. Try out test was conduted on Thursday 07th september 2017 at 09.00 A.M to 10:00 A.M. In the the first meeting the writer met Mom Piah Lit Samosir S.Pd (the teacher of English). The writer was accompanied by Mom Piah Lit Samosir S.Pd, to enter class 8D with 24 students for the try out test.

Before starting the test, the teacher and students prayed together after that the writer initiated the meeting by greeting and introducting him to the students and explained the purpose of her coming to the school in order to conduct a research for his sarjana's thesis. The students welcomed him friendly and they were enthusiastic.

The writer gave a little explaination about verb BE. The writer gave try out test which consisted of 25 questions for multiple choice items, 15 for simple translation form. When the time was up, the writer collected the students' worksheet and asked one of the students to say the prayer and left the class. The researcher analized the try out test, in order to see if the test was reliable or not, to know the allocation of the time was sufficient or not, to know whether the students understand the instruction of the test, and to find out item item difficulties and item power discrimination to select good items to be used in the real test.

According to Arikunto (2012:222) the index of difficulty of the tests are as follows:

$0.00-0.30 \quad$ : difficult

$0.31-0.70$ : moderate

$0.71-1.00$ : easy

Based on the data analysis from table item difficulties in multiple choice form for item number (2) there were 17 students who answered correctly and got 0.70 index level of difficulty, it means that item moderate for students (see appendix I). Items number (6) there were 20 students who answered correctly and got 0.83 index level difficulty, it means that item easy for students. Item number (8) there were 24 students who answered correctly and got 1.00 index level of difficulty, it means that item easy for students. Items number (9) there were 19 students who answered correctly and got 0.79 index level of difficulty, it means that item easy for students. Item number (13) there were 7 students who answered correctly and got 0.29 index level of difficulty, it means that item difficult for students. Item number (20) there were 7 students who answered correctly and got 0.29 index level of difficulty, it means that item difficult for students.

According to Arikunto (2012:228-232) the index of discrimination of the tests are as follows: 


$$
\begin{array}{ll}
0.00-0.20 & : \text { poor } \\
0.21-0.40 & : \text { satisfactory } \\
0.41-0.70 & : \text { good } \\
0.71-1.00 & \text { : excellent }
\end{array}
$$

Based on the data analysis from table item discrimination in multiple choice form, it showed that item number (2) got 0.58 index level of discrimination, it means that item good for students (see appendix II). Item number (6) got 0.33 index level of item discrimination, it means that item satisfactory for students. Item number (8) got 0.00 index level of item discrimination, it means that item poor for students. Item number (9) got 0.25 index level of item discrimination, it means that item satisfactory for students.

Try out test in simple translation form can not be analized with item difficulties and discrimination item because the students answered them with their own words, no choice available.

The result of the try out test in multiple choice form indicated that some items need revising or changing because they do not meet the requirements of a good test. Some items are so easy that the students can answer them correctly, on the other hand, some item tests are to easy too answer, such items should be revised changed or discarded.

The items met requirements based on the result of try out test in multiple choice form, they were number $1,2,4,5,6,7,9,10,11,12,15,17,18,19,22,24$, and 25 so, there were 17 items met requirements and 8 item did not meet the requirements, they were number 3,8,13,14,16,20,21, and but only 15 item are used to real test, they were number $1,2,4,5,7,10,12,15,17,18,19,21,22,24$, and 25 .

\section{Real Test}

After revising the try out test, the real test was conducted on Friday $11^{\text {th }}$ September 2017 starting 08.30 A.M to 09.30 A.M. The writer was accompanied by Mom Piah Lit Samosir S.Pd to class. Before the start of taking the test, the researcher and students prayed together. Then the reseacher opened the class saying good morning, asked their condition and checked the students' attendance list. After the reseacher checked the students attendance list, the reseacher administered the real test sheet to class $8 \mathrm{~A}, 8 \mathrm{~B}, 8 \mathrm{C}$ and $8 \mathrm{D}$ with 40 students in one class room. The test were 25 questions which consisted of 15 questions for multiple choice items, 10 items translation for completion form. When the time was up, the reseacher collceted the students' worksheet and one of students lead the prayer and left the class.

The next day, the writer started checking and anlyzing the real test. some students do not understand about the rule of verb BE, how to apply it in the sentences because there were a lot of rules and exception in verb BE. The students also had some difficulties in using verb $\mathrm{BE}$, such as the students did not know the form of some tense such as present tense and past tense. Before determining the verb BE from a sentence, they should know even master the form of tenses. The writer gave score one by one of worksheet students. Multiple choice were 15 items and translate 10 items. The writer gave in each of items in multiple choice the score was 4 and in each of item translation the score was 4 . If the students can answer all items in multiple choice form correctly, the score was 60 and if the students answered all items in translation form correctly the score 40. The total score was 100. (See Appendix III)

The writer calculated the coefficient correlation by using person product Moment formula to find out the reliability by Arikunto (2012:87). Then the writer calculated all of item test. Afterwards, the writer calculated mean and standard deviation. The writer classified the students into three groups high, moderate, and low. Then, the writer calculated the percentage of students who got high, moderate, and low.

After scoring the the test, it is found that the average score is 65.10 , the highest score is 100 with the total of correct answer 25 achieved by 1 students, and the lowest score with 36

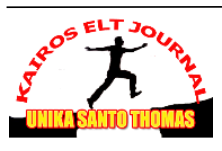


KAIROS ELT JOURNAL, Vol. 1, No. 3, December 2017

Copyright@2017, ISSN: 2580-4278

achieved by 2 students. To know the average score of the students' ability in SMP Katolik Trisakti 1 Medan, the researcher used formula:

Mean $=\frac{\sum X}{N}$

Mean $=\frac{2604}{40}$

Mean $=65.10$

After counting the mean result of the student's scores, the researcher counted the student's score into percentage by using the formula:

Mean $=\frac{\sum X}{N} \times 100 \%$

Mean $=\frac{2604}{40} \times 100 \%$

Mean $=65.10 \%$

Based on the interval of percentage of ability degree Minimal Criterion Mastery (KKM), the second year students of SMP Katolik Trisakti 1 Medan in using verb BE got $65.10 \%$ so the ability of second year students of SMP Katolik Trisakti 1 Medan in using verb $\mathrm{BE}$ is not yet able. The following table shows the percentage of students' score and categories based on the student's score.

Table 4.1 Classification of Students in Using Verb BE

\begin{tabular}{|l|l|}
\hline The Ability & Verb BE \\
\hline \multirow{2}{*}{ High } & 9 \\
\cline { 2 - 2 } & $22.50 \%$ \\
\hline \multirow{2}{*}{ Moderate } & 28 \\
\cline { 2 - 2 } & $70 \%$ \\
\hline \multirow{2}{*}{ Low } & 3 \\
\cline { 2 - 2 } & $7.50 \%$ \\
\hline
\end{tabular}

Based on the table above, the writer found were 9 students (22.50\%) got high catogory, 28 students $(70 \%)$ got category as moderate, and 3 students $(7.50 \%)$ got category. Based on the categorization group, the writer can conclude that students' ability in using BE was moderate. It was based on the fact that the majority of the students $(70 \%)$ had moderate ability.

But based on the total number of the students the writer found mean 65.10 with only 12 students who got score above 70 based on Minimal Criterion Mastery (KKM). The students were categorized 'able' in using verb BE if $70 \%$ total students answered all items correctly. It means that the second year students of SMP Katolik Trisakti 1 Medan were not able yet to use verb BE.

\section{Reliability of the Test}

Reliability is the extent to which a test is consistent in measuring whatever it does measure. Arikunto (2012:89) states that the categories of the reliability of the tests are as follows:

$0.00-1.00:$ : the reliability is very high

$0.60-0.80:$ : the reliability is very high

$0.40-0.60$ : the reliability is significant

$0.20-0.40:$ : the reliability is low

$0.00-0.20$ : the reliability is very low

So, this is the result of reliability of the real test verb BE in odd number and even number multiple choice and completion translation form by using person Product Moment the total 
KAIROS ELT JOURNAL, Vol. 1, No. 3, December 2017

Copyright@2017, ISSN: 2580-4278

0.80 and the coefficient correlation of reliability for total was 0.88 (see appendix IV). It means that the degree of coefficient correlation of the test was high and the test was reliable.

\section{Validity of the test}

A good test should test be valid and reliable. According to Arikunto (2012:82) to see the validity, the reseacher uses the content validity. Content validity was the degree to which a test measure an intended content area. Furthermore, on of characteristics of a good test was content validity in which the test materials were constructed based based on the curriculum. The test that the reseacher gave to the students based on the syllabus and teaching materilas that had been taught by the teacher to students. It means that the test was valid.

\section{The Research Findings}

As a result of the real test, the writer found out that the highest score got by the students in using verb BE was 100 and the lowest score was 36. Then the writer calculated standard deviation of the real test (see appendix $\mathbf{V}$ ).

According to Arikunto (2012:299) the students' ability can be classified based on their group. Students' ability was categorized as high if their scores were higher than $82.19(\mathrm{M}+1$ SD). Their abilities were categorized as moderate if their scores were in range 48.01 - 82.19 $((\mathrm{M}+1 \mathrm{SD})-(\mathrm{M}+1 \mathrm{SD}))$ and their abilities were categorized as low if their scores were lower than $48.01(\mathrm{M}+1 \mathrm{SD})$ (see appendix (VI).

Table 4.2. Mistakes Made Students Using Verb BE in Present Tense and Past Tense

\begin{tabular}{|c|c|c|c|c|c|}
\hline & Tense & & $\begin{array}{l}\text { Item } \\
\text { Number }\end{array}$ & $\begin{array}{l}\text { Incorrect } \\
\text { Answer }\end{array}$ & Percentage \\
\hline \multirow{25}{*}{$\begin{array}{l}\text { Verb } \\
\text { BE }\end{array}$} & \multirow{14}{*}{$\begin{array}{l}\text { Present } \\
\text { Tense }\end{array}$} & \multirow{7}{*}{$\begin{array}{l}\text { Multiple } \\
\text { Choice }\end{array}$} & 2 & 2 & \multirow{14}{*}{$28.57 \%$} \\
\hline & & & 3 & 20 & \\
\hline & & & 6 & 30 & \\
\hline & & & 9 & 15 & \\
\hline & & & 11 & 30 & \\
\hline & & & 12 & 14 & \\
\hline & & & 13 & 5 & \\
\hline & & \multirow[t]{7}{*}{ Essay } & 1 & 3 & \\
\hline & & & 2 & 0 & \\
\hline & & & 3 & 2 & \\
\hline & & & 5 & 1 & \\
\hline & & & 6 & 2 & \\
\hline & & & 7 & 1 & \\
\hline & & & 8 & 15 & \\
\hline & \multirow{11}{*}{$\begin{array}{l}\text { Past } \\
\text { Tense }\end{array}$} & \multirow{8}{*}{$\begin{array}{l}\text { Multiple } \\
\text { Choice }\end{array}$} & 1 & 0 & \multirow{11}{*}{$11.46 \%$} \\
\hline & & & 4 & 15 & \\
\hline & & & 5 & 23 & \\
\hline & & & 7 & 24 & \\
\hline & & & 8 & 23 & \\
\hline & & & 10 & 12 & \\
\hline & & & 14 & 28 & \\
\hline & & & 15 & 25 & \\
\hline & & \multirow[t]{3}{*}{ Essay } & 4 & 13 & \\
\hline & & & 9 & 23 & \\
\hline & & & 10 & 23 & \\
\hline
\end{tabular}


KAIROS ELT JOURNAL, Vol. 1, No. 3, December 2017

Copyright $\odot 2017$, ISSN: 2580-4278

\begin{tabular}{|l|l|l|l|l|l|}
\hline & Total & 25 & 349 & \\
\hline
\end{tabular}

Based on the table 4.2 the total incorrect answers made by the students in each tense was 349 . The table showed that the percentage mistakes made by students using verb Be in Present Tense was $28.57 \%$, and the percentage mistakes made by students using verb Be in Past Tense was $11.46 \%$, So the most mistakes made by the second year students in using verb Be was in present tense, the percentage was $28.57 \%$. Regarding Present Tense, the mistakes made by the students are verb-agrement, meanwhile in the simple translation form, most students omit the form of BE and the Past Tense, most students made mistakes in choosing the correct answer in the multiple choice form. In the simple translation it is way the same as in the Present Tense.

\section{Questioner}

Table 4.3 Questioner

\begin{tabular}{|c|c|c|c|}
\hline No & Question & Yes & No \\
\hline 1. & $\begin{array}{l}\text { I am listening to the teacher during the explanation about } \\
\text { the lesson of verb BE. }\end{array}$ & 10 Students & 30 Students \\
\hline 2 & I understand about the meaning of verb BE. & 20 Students & 20 Students \\
\hline 3 & I always do the best of verb BE. & 24 Students & 16 Students \\
\hline 4 & $\begin{array}{l}\text { The teacher tries her best to make students understand } \\
\text { about verb BE easily. }\end{array}$ & 39 Students & 1 Students \\
\hline 5 & $\begin{array}{l}\text { I always pay attention and not sleeping when learning of } \\
\text { verb BE. }\end{array}$ & 25 Students & 15 Students \\
\hline 6 & $\begin{array}{l}\text { If the test of verb BE I do not understand, I will learning } \\
\text { of verb BE. }\end{array}$ & 18 Students & 22 Students \\
\hline 7 & The lesson of verb BE is important to know & 19 Students & 21 Students \\
\hline 8 & $\begin{array}{l}\text { When teacher explanation about the lesson of verb BE, I } \\
\text { am paying attention seriously }\end{array}$ & 20 Students & 20 Students \\
\hline 9 & $\begin{array}{l}\text { if the teacher didn't task me about verb BE, I am not } \\
\text { interested in it. }\end{array}$ & 18 Students & 22 Students \\
\hline 10 & $\begin{array}{l}\text { My notes about the lesson of verb BE is not complete and } \\
\text { not neat. }\end{array}$ & 16 Students & 24 Students \\
\hline
\end{tabular}

Based on the interview sheet analysis, the writer concluded that the students did not want to ask the teacher if they did not understand about verb BE. The students were not interested if the teacher asked about verb BE. It means they did not study much about verb BE. Nearly all students had not written the lesson of verb BE when the teacher explained it. And about half of the students did not ask the teacher if they did not understand the lesson. From the analysis, it can be understood that they are not yet able to use verb BE since their mean score was only 65.10 .

\section{Discussion}

As the result of the research showed that 9 students (22.50) belong to high category, 28 students (70\%) to moderate catogory, and 3 students (7.50\%) to low category. Therefore based on the group, the ability of the second year students of SMP Katolik Trisakti 1 Medan in using verb BE was moderate (70\%) (see appendix VII). But based on totality of the students the writer found 65.10 for mean and 17.09 for standard deviation. There were 12 students who got score above 70 who passed the Minimal Criterion Mastery (KKM) from 40 students who followed the test. It means that the second year students at SMP Katolik Trisakti 1 Medan are 
not able yet to use verb BE because only $30 \%$ (students) who passed the minimal criteriion mastery whereas according to the rule, there must be $70 \%$ of the total students who score above 70 in order to be said "able". Therefore, it can be concluded that the second grade students of SMP Katolik Trisakti 1 Medan are not yet able to use the verb BE.

Based on the table 4.2 the total incorrect answers made by the students in each tense was 349. The table showed that the percentage mistakes made by students using verb Be in Present Tense was $28.57 \%$, and the percentage students mistakes made by using verb Be in Past Tense was $11.46 \%$, So the most mistakes made by the second year students in using verb Be was in present tense, the percentage was $28.57 \%$.

The writer correlated the result of the test and interview sheet why the students are not able in using verb BE bacause the students did not want to ask the teacher if they do not understand about verb BE, the students were not interested if the teacher asks about verb BE, they were lazy to writer verb BE in the notes book, and the teacher gave the material about verb BE inadequately, so it did not reach the students' mind. Perhaps, the inability of the students in using verb BE results from two factors, namely the teacher and the students themselves.

Teacher should give motivation in learning teaching process. When students succeed, teacher should praise their effort or their strategies, not their intelligence. When the students fail, teacher should also give feedback about effort or strategies what the students did wrong and what they could do now. They may feel that they have no interest in the subject, so the teacher is expected to create the teaching strategy effectively and interestingly so that the students can follow the lesson well in the class. The teacher is expected to give explanation of the materials of verb BE crearly and give the assignments to the students to do at home. This assignment should crearly be corrected by the teacher, and ruterned to the students.

The students are suggested to ask the teacher if they do not understand the materials, so that it will not be difficult for them to continoue to the next materials. The teacher should pay attention to the students' attitude during learning teaching process because of the students noisy and playing, it will be difficult for them to understand the subject being taught.

\section{CONCLUSIONS}

The conclusions of this research are presented based on the data which have been analyzed in the previous chapter. From all the data analysis about the ability of the second year students in using verb BE, it can be concluded as follows:

1. Based on the total number of the students, the writer found out only 12 students who get score above 70 and passed the Minimal Criterion Mastery (KKM). It means that the second year students at SMP Katolik Trisakti 1 Medan are not yet able to use the verb BE because only $30 \%$ of the total students who can do the test well. Whereas $70 \%$ of the students can not do the test well. The regulation of saying ability is fulfilled if $70 \%$ of the total number of the students can do the test well.

2. Based on the ranking group the ability of the third year students of SMP Katolik Trisakti 1 Medan in using verb BE was moderate category (70\%) with the score in range 48.0182.19. The writer found out 9 students belong to high category $(22.50 \%)$ with the score 82.19 , and 3 students to low category $(22.85 \%)$ with the score 48.01 .

3. Based on the total incorrect answers made by the students in each tense was 349 . The table showed that the percentage of the mistakes made by students using verb $\mathrm{Be}$ in Present Tense was $28.57 \%$, and the percentage mistakes made by students using verb Be in Past Tense was $11.46 \%$, So the most mistakes made by the second year students in using verb Be was in present tense, the percentage was $28.57 \%$. Based on checking and analyzing the real test, some students were not understand about the rule of verb $\mathrm{BE}$, how to apply it in the sentence because there were a lot of rules and exceptions in 
KAIROS ELT JOURNAL, Vol. 1, No. 3, December 2017

Copyright@ 02017 , ISSN: 2580-4278

verb BE. The students also had some difficulties in using verb BE, such as to determine the approprite pronoun and auxiliary in making verb BE. Moreover, the students did not know the form of some tenses such as present tense, past tense,etc. They could not know what appropriate verb BE in every sentences was. Before determining the verb BE form a sentence, they should know even master the form of tenses.

4. Based on the interview sheet, it is found out that the students did not ask for explation if they did not understand the verb BE. They are not interested either in that subject if the teacher asks them about the verb BE. The students were lazy to write about the verb $\mathrm{BE}$ in the notes book, and the teacher gave the material about verb BE inadequately, so it did not reach the students' mind.

\section{BIBLIOGRAPHY}

Arikunto, S. 2012. Dasar-Dasar Evaluasi Pendidikan Edisi Kedua. Jakarta: Bumi Aksara. Arikunto, Sumarsimi. 2006. Prosedur Penelitian. Jakarta: Rineka Cipta. 2002. Prosedur Penelitian Suatu Pendekatan Praktik. Jakarta: Rineka Cipta

Arshad, A.S \& Hawanum, H. 2010. Teaching Grammar and What Student Ability In the Use of the English Auxiliary 'Be' Can Tell Us The English Teacher. Malaysia.

Azar, Betty. S.\& Hagen, Stacy.A. 2006. Basic English Grammar. New York: Pearson Longman.

Baker, Mona. 1992. In Other Words: A Coursebook On Translation. New York: Routledge.

Bhatia, Manish. S. 2009 Dictionary of Psychology and Alled Sciences: New Delhi: New Age International (P) Ltd., Publishers

Carrol, John. B. 1993. Human Cognitive Abilities: A Survey of Factor-Analytic Studies. New York: CambridgeUniversity Press.

Dykes, Barbara. 2007. Grammar For Everyone: Pratical Tools for Learning and Teaching. Sydney: Council for Educational Research Ltd.

Farhanaz, Mohd Baldev Shah. 2007. The Acquisition of "To Be" as an Auxiliary Verb and a Lingking Verb in the Written Work of Malaysia ESL Learners (Master's Thesis). Islamic International University Malaysia, Gombak, Selangor.

Francis, Nelson. W. 1954. Grammars, and Teaching of Grammar. New York: Ronald Press company.

Fernald, James. G. 1975. English Grammar Simplified. New York: Barnes \& Noble Books.

Hall, Eugene. J. 1993. Grammar for Use: a Realitis Approach to Grammar Study for Immediate and Pratical Application. Jakarta: Binarupa Aksara.

Johnson, Burker. R. \& Christensen, Larry. B. 2008. Educational Research. California: Sage Publications, Inc. 
KAIROS ELT JOURNAL, Vol. 1, No. 3, December 2017

Copyright $\odot 2017$, ISSN: 2580-4278

Knight, John. 2010. Methods and Instruments of Data Collection. Retrieved on June 21 st, 2014, from http://www.scribd.com/doc/37790831/Methods-and- Instruments-of-DataCollection.

Limbong, T., \& Simarmata, J. (2020). Menentukan Matakuliah yang Efektif Belajar Daring (Belajar dan Ujian) dengan Metode Multi-Attribute Utility Theory (MAUT). Jurnal Resti, 4(2), 370-376.

Palmer, Frank. R. 1965. The English Verb 2nd Edition. New York: Addison Wesley Longman inc.

Peters, Pam. 2004. The Cambridge Guide English Usage. New York: Cambridge University Press.

Saadiyah Darus \& Subramaniam, K. (2009). Error Analysis of the Written English Essays of Secondary Schools Students in Malaysia: A Case Study. European Journal of Social Science.

Surina Nayan, \& Kamaruzaman Jusoff. 2009. A Study of Subject-Verb Agreement: from Novice Writers to Expert Writers. International Education Studies.

Swan, Michael. 2005. Practical English Usage. Third Edition. London: Oxford University Press.

Wren, Martin. 1986. High School English Grammar and Composition. Hundred and Seventeenth Edition. New Delhi: S. Chand \& Company Ltd. 